\title{
Üniversite Öğrencilerinin Disleksi Hastalığı Hakkındaki Bilgi Düzeylerinin Belirlenmesi (Gümüşhane Üniversitesi Örneği)
}

\author{
Determination of Knowledge Level of University Students on Dyslexia (Gümüşhane University \\ Example) \\ Nilgün ULUTAŞDEMİR ${ }^{1}$, Sevda UZUN ${ }^{2}$, Nurşen KULAKAÇ ${ }^{3}$, Hanım SARI $^{4}$, Meryem ACAR $^{5}$
}

\begin{abstract}
ÖZ
$\mathrm{Bu}$ araştırma üniversite öğrencilerinin disleksi hastalığı hakkındaki bilgi düzeylerinin belirlenmesi amacıyla yapılmıştır. Tanımlayıcı türdeki araştırmanın evrenini Gümüşhane Üniversitesi öğrencileri oluşturdu. Araştırmada 1500 öğrenciye ulaşılmıștır ve veri toplama formu olarak araştırmacılar tarafından hazırlanan anket formu kullanılmıştır. Araştırmaya katılan öğrencilerin yaş ortalaması $21.21 \pm 1.95$ 'dir. Öğrencilerin \%40,7'si sağlık bilimleri fakültesinde öğrenim görmektedir ve öğrencilerin \%42.6'sını disleksi hakkında bilgi sahibi olduğu saptanmıştır. Öğrencilerden disleksiyi tanımlamaları istendiğinde \%49.1'i disleksiyi öğrenme bozukluğu olarak tanımlarken, \%24.9'u sosyal iletişimde bozukluk, $\% 17,7$ 'si zeka geriliği, \%4,7'si bedensel engel \%3.7'si de işitsel engel olarak tanımlamıştır. Araştırmamız sonucunda öğrencilerin çoğunluğunun disleksi kavramını duymadıkları ve disleksi ile ilgili herhangi bir kitap okumadıkları belirlenmiştir. Disleksi konusunda farkındalık kampanyaları sayısının artırılarak disleksi araştırmalarının geniş örneklemlerde yapılması ve sonuçlar doğrultusunda disleksi konusunda stratejik planlamalar yapılması önerilmektedir. Ayrıca Türkiye'de disleksi ile ilgili sistematik araştırmalar yapılmalı, güçlük çeken öğrencilerin ihtiyaçları doğrultusunda bireyselleştirilmiş etkinlikler ve programlar
\end{abstract} hazırlanmalıdır.

Anahtar Kelimeler: Disleksi, Bilgi düzeyi, Üniversite öğrencileri

\begin{abstract}
This research was conducted to determine the knowledge level of university students about dyslexia. Gümüşhane University exam constituted the universe of the descriptive research. 1500 students were reached in the study and a questionnaire form was used by the research as a data collection form. The average age of the study is $21.21 \pm 1.95 .40 .7 \%$ of the students are studying at the faculty of health sciences and $42.6 \%$ of the students have knowledge about dyslexia. When the students were asked to define dyslexia, $49.1 \%$ defined dyslexia as learning disorder, $24.9 \%$ defined social communication disorder, $17.7 \%$ mental retardation, $4.7 \%$ physical disability and $3.7 \%$ identified auditory disability. Our research is because they haven't heard of rocker dyslexia concept and haven't read any books on dyslexia. It is recommended to increase the number of possible awareness campaigns and make plans for dyslexia studies to be conducted in large samples and to be put on the market. In addition, systematic research on dyslexia should be done in Turkey, personalized programs and programs to others by drawing others to be prepared.
\end{abstract}

Key Words: Dyslexia, Knowledge level University students

\footnotetext{
${ }^{1}$ Doç. Dr, Nilgün ULUTAŞDEMİR, Halk Sağlığı, Gümüşhane Üniversitesi, Sağlık Bilimleri Fakültesi, Sağlık Yönetimi Bölümü, nulutasdemir@yahoo.com, ORCID: : 0000-0002-2231-5236

${ }^{2}$ Arş. Gör, Sevda UZUN, Psikiyatri Hemşireliği, Gümüşhane Üniversitesi, Sağlık Bilimleri Fakültesi, Hemşirelik Bölümü, sevdauzun50@gmail.com, ORCID: 0000-0002-5954-717X

${ }^{3}$ Öğr. Gör, Nurşen KULAKAÇ, Cerrahi Hemşireliği, Gümüşhane Üniversitesi, Sağllk Bilimleri Fakültesi, Hemşirelik Bölümü, nrsnklkc@gmail.com, ORCID: 0000000254271063

${ }^{4}$ Hemsire, Hanım SARI, Karadeniz Üniversitesi Tıp Fakültesi, Farabi EAH, hanim61mavi@ gmail.com, ORCID: 0000000157373850

${ }^{5}$ Hemşire, Meryem ACAR, acarmeryem46@gmail.com, ORCID: 0000000284472392
} 


\section{GİRIȘ}

Disleksinin kelime köküne bakıldığında Yunancada yetersizlik anlamında kullanılan "dys" kelimesine "lexia" kelimesinin eklenmesi sonucunda ortaya çıkmıştır. Bu kapsamda disleksi bireylerin; yaş ve ölçülebilen zekâ düzeyleri ile eğitim seviyeleri göz önünde bulundurulduğunda okuma başarısının beklentilerin altında olması ile tanımlanabilir. ${ }^{1}$ Disleksi, en yaygin olan öğrenme güçlüklerinden biridir. ${ }^{2}$

Ruhsal Bozuklukların Tanısal ve Sayımsal El Kitabı Beşinci Baskısında, ${ }^{3}$ disleksi, sözcük tanıma doğruluğu ya da akıcılığı sorunları, anlaşılır dile çevirme güçlüğü, harf harf söyleme ve yazma güçlükleri örüntüsü ile ifade edilmektedir. ${ }^{3}$ Gelişimsel disleksi (primer veya spesifik disleksi), özgül okuma bozukluğu olarak da bilinir. Gelişimsel disleksi öğrenme bozukluklarının \%80'ini oluşturur. Disleksi üstün zekâlı veya IQ seviyesi düşük olan çocuklarda da açığa çıkabilir. ${ }^{4}$ Boder, klinik bulgular temelinde halen yaygın kabul gören üç tip okuma bozukluğu saptamıştır. ${ }^{5}$ Buna göre disfonetik okuma bozukluğu (harf-ses ilişkisi bozulur), diseidetik okuma bozukluğu (kelimeleri bir bütün halinde okuyamaz; harf harf okur veya hiç okuyamaz) ve bunların karışımından oluşan üçüncü tip okuma bozukluğu vardır. ${ }^{4}$ Bunlardan ilki olan disfonetik disleksiye baktığımızda görsel-işitsel bağlantı yokluğunda görsel imge bir ses uyandırmaz. Olguların yaklaşık 2/3'ünü bu grup oluşturur. Gelişimsel konuşma bozukluğu olan çocuklarda bu disfonetik disleksi gelişebilir. Disfonetik disleksiye dilsel disleksi de denilebilir., ${ }^{46}$ Diseidetik disleksi diğer bir adiyla görsel disleksi, disfonetik disleksiye göre daha seyrek olarak (\%5) görülmektedir. ${ }^{4}$
Karma disleksi: Hem işitsel hem de görsel dislektiklerin yaptıkları hataları yapmaktadırlar. Hem harf ve kelimelerin yazımında hem de harflerin seslerini hatırlamakta güçlük çekerler. ${ }^{7} \mathrm{Bu}$ bireyler akranlarına göre daha sistematik ve açık bir şekilde okuma talimatlarını içeren, okuma seviyeleri doğrultusunda tasarlanmış ve kişiselleştirilmiş bir okuma eğitimine muhtaçtır. Okuma eğitimleri disleksinin temel zorluklarına yönelik müdahale stratejilerini içermelidir. ${ }^{8}$ Algısal, görsel-motor, fonolojik farkındalığın artırılması gibi teknikler ve özel programlar eğitimde kullanılan farklı metotlardır. ${ }^{9}$ Her hastalığın tedavi sürecinde önemli olan durum erken teşhistir. Disletiklerin erken fark edilmesi onların yaşantılarında önemli bir konumda yer almaktadır. Disletiklerin fark edilememesi onların sosyal ortamdan ve eğitimle ilgili konulardan uzaklaşmasına neden olmaktadır. $\mathrm{Bu}$ nedenle dislekside erken tanı hayati önem taşımaktadır. ${ }^{10}$ Disleksi görülme sıklığına baktığımızda toplumumuzda disleksi görülme oranı \%5-\%7 arasındadır. ${ }^{11}$ Geleceğin anne babaları olarak üniversite öğrencilerinin disleksi konusunda farkındalık kazanması ve bu konuda bilgi sahibi olması önemlidir.

$\mathrm{Bu}$ araştırma üniversite öğrencilerin disleksi konusundaki farkındalıklarının saptanması, disleksi ile ilgili bilgi eksikliğinin belirlenmesi ve etkileyen faktörlerin belirlenmesi amacıyla yapılmıştır. $\mathrm{Bu}$ araştırma üniversite öğrencilerin disleksi konusundaki farkındalıklarının saptanması, disleksi ile ilgili bilgi eksikliğinin belirlenmesi ve etkileyen faktörlerin belirlenmesi amacıyla yapılmıştır.

\section{MATERYAL VE METOT}

\section{Araştırmanın Evreni ve Örneklemi}

$\mathrm{Bu}$ araştırma üniversite öğrencilerin disleksi konusundaki farkındalıklarının saptanması, disleksi ile ilgili bilgi eksikliğinin belirlenmesi ve etkileyen faktörlerin belirlenmesi amaciyla yapılmıştır. Tanımlayıcı türdeki araştırmanın evrenini, 1
Kasım 2018-30 Haziran 2019 tarihleri arasında bir üniversitede öğrenim gören öğrencilerin tamamı oluşturdu. $(\mathrm{n}=19,630)$. Örneklemin belirlenmesi için Open epi programı kullanıldı. \%99.99 güven aralığında 1406 öğrencinin araştırma kapsamına alınması gerektiği saptandı. Araştırmaya katılmayı gönüllü olarak kabul eden, 
çalışmanın yapıldı ğı günlerde okulda bulunan 1500 öğrenci oluşturmuştur.

\section{Veri Toplama Araçları ve Verilerin Toplanmasi}

Veri toplama aracı olarak literatür taraması yapılarak araştırmacılar tarafından geliştirilen anket formu kullanılmıştır. Anket formu öğrencilerin disleksi ile ilgili bilgi düzeylerini ve farkındalıklarını değerlendiren sorulardan oluşmaktadır.

\section{Verilerin Değerlendirilmesi}

Araştırmadan elde edilen veriler SPSS (Statistical Package for Social Sciences) 22,0 paket programı kullanılarak analiz edildi. Verilerin değerlendirilmesinde, aritmetik ortalama, sayı ve yüzdelik hesapları yapıldı.

\section{Araştırmanın Etik Yönü}

$\mathrm{Bu}$ çalışma Gümüşhane Üniversitesi Bilimsel Araştırma ve Yayın Etiği Kurulu (2018/9 sayılı) tarafından onanmış ve gerekli kurum izinleri alınarak yapılmıștır. Veri toplama formu doldurulmadan önce öğrencilere çalışmanın amacı hakkında bilgilendirme yapılarak çalışmaya katılmayı isteyip istemedikleri sorulmuş ve gönüllülük ilkesi doğrultusunda veri toplama formları direkt gözlem altında uygulanmıştır.

\section{Araștırmanın Sınırlılıkları}

Araştırma 1 Kasım 2018-Haziran 2019 tarihleri arasında bir devlet üniversitesinde öğrenim gören öğrenciler ile sınırlıdır. Tüm üniversite öğrencilerine genellenemez.

\section{BULGULAR VE TARTIŞMA}

Araştırmaya katılan öğrencilerin yaş ortalamas1 21,21 $1,95^{\prime}$ 'dir. Öğrencilerin $\% 40,7$ 'si sağlık bilimleri fakültesinde öğrenim görmekte ve \% 45,1'i Anadolu Lisesi'nden mezun olmuştur (Tablo 1).

Tablo 1. Öğrencilerin Tanımlayıcı Özelliklerinin Dağılımı

\begin{tabular}{|c|c|c|}
\hline Tanıtıcı Bilgiler & $\mathbf{N}$ & $\%$ \\
\hline \multicolumn{3}{|l|}{ Mezun Olunan Lise } \\
\hline Anadolu Lisesi & 667 & 45.1 \\
\hline Düz Lise & 351 & 23.4 \\
\hline Sağlık Meslek Lisesi & 108 & 7.2 \\
\hline Diğer & 364 & 24.3 \\
\hline \multicolumn{3}{|l|}{ Bölüm } \\
\hline Sağlık Bilimleri Fakültesi & 611 & 40.7 \\
\hline Mühendislik Fakültesi & 180 & 12.0 \\
\hline $\begin{array}{l}\text { İktisadi ve İdari Bilimler } \\
\text { Fakültesi }\end{array}$ & 372 & 24.8 \\
\hline Edebiyat Fakültesi & 218 & 14.5 \\
\hline Meslek Yüksek Okulu & 118 & 7.9 \\
\hline
\end{tabular}

Öğrencilerin \%42,6'sının disleksi hakkında bilgi sahibi olduğu, cevap verenlerin $\% 17,5$ 'inin örgün eğitim sürecinde, $\% 14,2$ 'sinin internetten, \% $\%$,4'ünün televizyon ve radyodan 'disleksi' hakkında bilgi sahibi olduğu belirlenmiştir. Öğrencilerden disleksiyi tanımlamaları istendiğinde \%49,1'i disleksiyi öğrenme bozukluğu olarak tanımlarken, \%24,9'usosyal iletişimde bozukluk, \%17,7'si zeka geriliği, $\% 4,7$ 'si bedensel engel \%3,7'si de işitsel engel olarak tanımlamıştır. Öğrencilerin $\% 89,1$ 'idisleksiile ilgili bir kitap okumadığını, $\% 7,5$ 'i 'disleksi' tanılı bir akrabasının olduğunu, \%64,8'i bebek doğmadan disleksinin belirlenemeyeceğini belirtmişlerdir. Ayrıca öğrencilerin \%78,0'1 disleksinin önlenebileceğini, \% 80,8'i disleksinin bir tedavisi olduğunu ve disleksinin tedavisi olduğunu düşünenlerin $\% 64,9$ 'u 'psikoterapi' ile tedavi edilebileceğini belirtmişlerdir (Tablo 2).

Öğrencilerin \%59,3'ü çocukta algısal bozukluk olmasını, \%52,9'u zihinsel gerilik olmasını, \%51,5'i gelişimsel sapma olmasını disleksi nedeni olarak belirttiği tespit edilmiştir. Ayrıca öğrencilerin \%85,4'ü 'ileri derecede düşük doğum ağırlığı', \%82,9'u 'fiziksel engel olma', \%73,3'ü 'erken doğum' olma durumlarını disleksi nedeni olarak belirtmedikleri saptanmıştır (Tablo 3). 
disleksi belirtisi olarak tanımlamıştır (Tablo

Tablo 2. Öğrencilerin Disleksiyi Bilme ve Farkında Olma Durumları

\begin{tabular}{|c|c|c|}
\hline & $\mathbf{N}$ & $\%$ \\
\hline $\begin{array}{l}\text { Disleksi hakkında bilgi sahibi } \\
\text { olma durumu } \\
\text { Evet } \\
\text { Hayır }\end{array}$ & $\begin{array}{l}639 \\
861\end{array}$ & $\begin{array}{l}42.6 \\
57.4\end{array}$ \\
\hline $\begin{array}{l}\text { Disleksi ile ilgili bilgi kaynağı } \\
\text { Televizyon } \\
\text { Örgün eğitim } \\
\text { İnternet } \\
\text { Yazılı kaynak } \\
\end{array}$ & $\begin{array}{c}111 \\
262 \\
213 \\
21 \\
\end{array}$ & $\begin{array}{c}7.4 \\
17.5 \\
14.2 \\
1.4 \\
\end{array}$ \\
\hline $\begin{array}{l}\text { Disleksiile ilgili kitap okuma } \\
\text { durumu } \\
\text { Evet } \\
\text { Hayır }\end{array}$ & $\begin{array}{c}163 \\
1337\end{array}$ & $\begin{array}{l}10.9 \\
89.1\end{array}$ \\
\hline $\begin{array}{l}\text { Disleksili bir akraba varlığı } \\
\text { Evet } \\
\text { Hayır }\end{array}$ & $\begin{array}{c}112 \\
1389\end{array}$ & $\begin{array}{c}7.5 \\
92.5\end{array}$ \\
\hline $\begin{array}{l}\text { Öğrencilere göre disleksi } \\
\text { tanımlamaları } \\
\text { Bedensel engel } \\
\text { İşitsel engel } \\
\text { Zeka geriliği } \\
\text { Sosyal-iletişimsel becerilerde } \\
\text { bozukluk } \\
\text { Öğrenme bozukluğu }\end{array}$ & $\begin{array}{c}70 \\
56 \\
265 \\
373 \\
736\end{array}$ & $\begin{array}{r}4.7 \\
3.7 \\
17.7 \\
24.9 \\
49.1\end{array}$ \\
\hline $\begin{array}{l}\text { Bebek doğmadan disleksi } \\
\text { belirlenebilir mi } \\
\text { Evet } \\
\text { Hayır }\end{array}$ & $\begin{array}{l}528 \\
972\end{array}$ & $\begin{array}{l}35.2 \\
64.8\end{array}$ \\
\hline $\begin{array}{l}\text { Disleksi bir tedavisi var mı } \\
\text { Evet } \\
\text { Hayır }\end{array}$ & $\begin{array}{c}1212 \\
228\end{array}$ & $\begin{array}{l}80.8 \\
19.2\end{array}$ \\
\hline $\begin{array}{l}\text { Disleksinin tedavisi nasıl yapılır } \\
\text { İlaç tedavisi } \\
\text { Psikoterapi } \\
\text { Aile tedavisi } \\
\text { Diğer*(kompansatuar yöntemler } \\
\text { vb.) }\end{array}$ & $\begin{array}{l}245 \\
974 \\
163 \\
118\end{array}$ & $\begin{array}{r}16.3 \\
64.9 \\
10.9 \\
7.9\end{array}$ \\
\hline $\begin{array}{l}\text { Disleksi önlenebilir mi } \\
\text { Evet } \\
\text { Hayır }\end{array}$ & $\begin{array}{c}1170 \\
330\end{array}$ & $\begin{array}{l}78.0 \\
22.0\end{array}$ \\
\hline
\end{tabular}

Öğrencilerin büyük çoğunluğu $(\% 73,8)$ 'konuşmayı öğrenmede gecikme' durumunu disleksi belirtisi olarak tanımlarken, $\% 60,5$ 'i 'sözlü ve yazılı dili organize edememe' \%55'i 'akı1 okumada sorun yaşama', \%53,6's1 'uzun olan okuma metinlerini takip etme ve anlamada sorun yaşama', \% 26,7'si 'hiperaktivite', \%73,3'ü 'harfleri ya da onlara ait sesleri yeterince öğrenememe' durumlarını
4).

Ayrıca öğrencilerin \%50,9'u 'numaraları ezberlemede sıkıntı yaşama', \%63,6's1 'yabancı bir dil öğrenmede problem yaşama', $\% 57,9$ 'u 'matematiksel işlemleri yapmada sıkıntı yaşama' durumunu disleksi belirtisi olarak tanımlamamıştır (Tablo 4).

Bu araştırma Türkiye'deki üniversitelerde eğitim gören öğrencilerinin disleksi ile ilgili bilgi düzeyini ve farkındalığını inceleyen ilk ve tek araştırmadır. Araştırmamızda öğrencilerin \%42.6'sının disleksi hakkında bilgi sahibi olduğu saptanmıştır. Balcı (2019)'da öğretmenler ile yaptığ 1 çalışmada öğretmenlerin sadece \% 25'inin disleksiyi tanıdığını, \% 75'inin ise tanıyamadığını saptamıştır. $^{12}$

Tablo 3. Öğrencilere Göre Disleksi Nedenleri*

\begin{tabular}{llcc}
\hline & & & \\
& & $\mathbf{N}$ & \% \\
\hline Beyin hasarı & Evet & 744 & 49.6 \\
& Hayır & 756 & 50.4 \\
\hline Gelişimsel & Evet & 722 & 51.5 \\
sapma & Hayır & 728 & 48.5 \\
\hline Genetik, & Evet & 690 & 46.0 \\
kalıtımsal & Hayır & 810 & 54.0 \\
etmenler & & & \\
\hline Algisal & Evet & 890 & 59.3 \\
bozukluklar & Hayır & 609 & 50.6 \\
\hline Nörolojik & Evet & 667 & 44.5 \\
fonksiyonlarda & Hayır & 883 & 55.5 \\
bozukluk & & & \\
\hline İleri derecede & Evet & 219 & 14.6 \\
düşük doğum & Hayır & 1281 & 85.4 \\
ağırlı̆̆1 & & & \\
\hline Erken doğum & Evet & 401 & 26.7 \\
& Hayır & 1099 & 73.3 \\
\hline Zihinsel gerilik & Evet & 793 & 52.9 \\
& Hayır & 707 & 47.1 \\
\hline Fiziksel engel & Evet & 257 & 17.1 \\
olma & Hayır & 1242 & 82.9 \\
\hline Birden çok șar & &
\end{tabular}

*Birden çok şık işaretlenmiştir 
Tablo 4. Öğrencilere Göre Disleksi Belirtileri*

\begin{tabular}{|c|c|c|c|}
\hline & & $\mathbf{N}$ & $\%$ \\
\hline \multirow{2}{*}{$\begin{array}{l}\text { Konuşmayı } \\
\text { öğrenmede gecikme }\end{array}$} & Evet & 1107 & 73.8 \\
\hline & Hayır & 393 & 26.2 \\
\hline \multirow{2}{*}{$\begin{array}{l}\text { Sözlü ve yazılı dili } \\
\text { organize edememe }\end{array}$} & Evet & 907 & 60.5 \\
\hline & Hayır & 593 & 39.5 \\
\hline \multirow{2}{*}{$\begin{array}{l}\text { Numaraları } \\
\text { ezberlemede sıkıntı } \\
\text { yaşama }\end{array}$} & Evet & 737 & 49.1 \\
\hline & Hayır & 763 & 50.9 \\
\hline \multirow{2}{*}{$\begin{array}{l}\text { Akıcı okumada } \\
\text { sıkıntı yaşama }\end{array}$} & Evet & 825 & 55.0 \\
\hline & Hayır & 675 & 45.0 \\
\hline \multirow{2}{*}{$\begin{array}{l}\text { Uzun okuma } \\
\text { parçalarını takip etme } \\
\text { ve anlamada sorun } \\
\text { yaşama }\end{array}$} & Evet & 804 & 53.6 \\
\hline & Hayır & 696 & 46.4 \\
\hline \multirow{2}{*}{$\begin{array}{l}\text { Yazmada güçlükler } \\
\text { yaşama }\end{array}$} & Evet & 750 & 50.0 \\
\hline & Hayır & 750 & 50.0 \\
\hline \multirow{2}{*}{$\begin{array}{l}\text { Yabancı bir dil } \\
\text { öğrenmede problem } \\
\text { yaşama }\end{array}$} & Evet & 546 & 36.4 \\
\hline & Hayır & 954 & 63.6 \\
\hline \multirow{2}{*}{$\begin{array}{l}\text { Matemetiksel } \\
\text { işlemleri yapmada } \\
\text { sıkıntı yaşama }\end{array}$} & Evet & 632 & 42.1 \\
\hline & Hayır & 867 & 57.9 \\
\hline \multirow{2}{*}{$\begin{array}{l}\text { Hiperaktivite } \\
\text { (aşırı hareketlilik) }\end{array}$} & Evet & 400 & 26.7 \\
\hline & Hayır & 1100 & 73.3 \\
\hline \multirow{2}{*}{$\begin{array}{l}\text { Harfleri ya da onlara } \\
\text { ait sesleri yeterince } \\
\text { öğrenememe }\end{array}$} & Evet & 1100 & 73.3 \\
\hline & Hayır & 400 & 26.7 \\
\hline
\end{tabular}

*Birden çok şık işaretlenmiştir.

Araştırmamızda öğrencilerin \%17,5'inin örgün eğitim sürecinde, \%14,2'sinin internetten, \%7,4'ünün televizyon ve radyodan disleksi ile ilgili bilgi aldığ belirlenmiştir. Soriano-Ferrer ve arkadaşlarının 2016 yılında öğretmenlerle yapmış olduğu çalışmada öğretmenlerin \%40,6'sının kitaplardan, \%31,3'ünün radyo ve televizyondan, \%17,6'sının özel Balcı (2019)' da yaptığı çalışmada öğretmenlerin, \% 6'sının hafıza problemi olarak, \% 5'nin ise konuşmada yaşanan zorluk olarak disleksiyi tanımladığını ifade etmiştir. dergilerden, \%10,5'inin özel kurs ve konuşmalardan disleksi hakkında bilgi sahibi olduğu saptanmıştır. ${ }^{13}$ Çalışmamızda ögrencilerin \%7,5'inin 'disleksi' tanılı bir akrabasının olduğu belirlenmiştir. UluçınarSağır ve Bozgun'un (2018) öğretmenlerle yaptığ1 çalışmada öğretmenlerin \% $\% 9,2$ 'sinin öğrenme güçlüğü çeken bir akrabasının olduğu saptanmıştır. ${ }^{14}$

Öğrencilerin $\quad \% 78,0{ }^{\prime} 1$ disleksinin önlenebileceğini, \% 80,8'i disleksinin bir tedavisi olduğunu ve disleksinin tedavisi olduğunu düşünenlerin \%64,9'u 'psikoterapi' ile tedavi edilebileceğini belirtmişlerdir.

Balc1 (2019)'da yaptığı çalışmada öğretmenlerin \% 25'inin disleksiyi öğrencinin öğrenememesi ve akademik olarak geride kalması durumu olarak tanımladığını belirtmiştir. ${ }^{12}$ Araştırma bulgularına bakıldığında öğrencilerin $\% 59,3$ 'ü çocukta algısal bozukluk olmasını, \%52,9'u zihinsel gerilik olmasını, \%51,5'i gelişimsel sapma olmasını disleksi nedeni olarak belirttiği tespit edilmiştir. $\mathrm{Bu}$ durum öğrencilerin disleksiyi algısal bozukluk olarak gördüklerini düşündürebilir. Öğrencilerin büyük çoğunluğu $(\% 73,8)$ 'konuşmayı öğrenmede gecikme' durumunu disleksi belirtisi olarak tanımlarken, \%60,5'i 'sözlü ve yazılı dili organize edememe', \%55'i 'akıcı okumada sorun yaşama' , \%53,6's1 'uzun okuma metinlerini takip etme ve anlamada sorun yaşama', \% 26,7'si 'hiperaktivite', \%73,3'ü 'harfleri ya da onlara ait sesleri yeterince öğrenememe' durumlarını disleksi belirtisi olarak tanımlamıştır.

Öğrencilerin \%50,9'u 'numaraları ezberlemede sorun yaşama', \%63,6's1 'yabancı bir dil öğrenmede problem yaşama', $\% 57,9$ 'u 'matematiksel işlemleri yapmada sorun yaşama' durumunu disleksi belirtisi olarak tanımlamamıştır.

Ayrıca Balcı çalışmasında öğretmenlerin \% 4'ünün de disleksi ile ilgili hiçbir şey bilmediğini saptamıştır. ${ }^{12}$ 


\section{SONUÇ VE ÖNERILER}

Araştırma kapsamında üniversite öğrencilerinin disleksi ile ilgili bilgi düzeylerinin saptanması hedeflenmiştir. Araştırmamız sonucunda öğrencilerin çoğunluğunun disleksi kavramını duymadıkları ve disleksi ile ilgili herhangi bir kitap okumadıkları belirlenmiştir.

Dünyada yaygınlığı gün geçtikçe artan disleksinin araştırılması ve tedavisi oldukça zaman almaktadır. Araştırılması ve tedavisi için oldukça zaman harcanan disleksi de erken tanı çok önemlidir. Bu yönden ele alındığında geleceğin anneleri ve babaları olan üniversite öğrencilerinin disleksi konusunda farkındalık kazanmaları önem arz etmektedir. Disleksi tam olarak anlaşılmadığından ya da önemsenmediğinden dolayı tedavide gecikmeler yaşanmakta ve bireylerin hayatları oldukça kötü yönde etkilenmektedir. Disleksi konusunda üniversitelerde eğitim verilmesi, disleksi araștırmalarının geniş örneklemlerde yapılması ve sonuçlar doğrultusunda disleksi konusunda stratejik planlamalar yapılması önerilmektedir. Ayrıca disleksi ile ilgili problem yaşayan öğrencilerin erken tanılanmaları oldukça önemlidir ve tanılanan bireylerin ihtiyaçları doğrultusunda bireysel etkinlikler ve programlar planlanmalı ve uygulanmalidir.

\section{Çalışma Literatüre Ne Kattı?}

Üniversite öğrencilerinin disleksi hastalığ hakkındaki bilgi düzeyleri belirlenmiștir. Geleceğin anneleri ve baba adayları olan üniversite öğrencilerinin disleksi konusunda bilgi düzeylerinin önemli olduğu ve disleksi konusunda eğitimlere ve bilgilendirmelere ihtiyaç olduğu saptanmıştır. Gelecekte yapılacak çalışmalara kaynak olması ve katkı sağlaması açısından önemlidir.

\section{KAYNAKLAR}

1. Munawaroh, M, Yogakarta, U.P, Anggrayni, N.T. and Yogakarta, U. P. (2015). "Mengenalı Tanda-Tanda Disleksıa Pada Anak Usıa Dını, Proseding Seminar Nasional PGSD UPY dengan Tema Strategi Mengatasi Kesulitan Belajarketika Murid AndaSseorang.” Disleksia, 167-171.

2. Cope, N, Harold, D, Hill, G, Moskvina, V, Stevenson, J, Holmans, P, Owen, M.J., O’Donovan, M. and Williams, J. (2005)." Strongevidence That KIAA0319 On Chromosome 6p İs A Susceptibility Gene For Developmental Dyslexia".i The Amerikan Journal of Human Genetics, 76, 581-591.

3. Köroğlu, E. (2014). Amerikan Psikiyatri Birliği. Ruhsal Bozuklukların Tanısal ve Sayımsal Elkitabı, Beșinci Bask (DSM-5), Tanı Ölçütleri Başvuru Elkitabı [Diagnostic and statistical manual of mental disorders]. Hekimler Yayın Birliği: Ankara.

4. Salman, U, Özdemir, S, Salman, A. B. ve Özdemir, F. (2016) “Özel Öğrenme Güçlügü; Disleksi”. İstanbul Bilim Üniversitesi Florence Nightingale Tip Dergisi, 2(2), 170-176, doi:10.5606/fng.btd.2016.031

5. Erman, Ö. (2002). "Disleksi”. Coluk Cocuk Dergisi, 17, 810.
6. Maughan, B. ve Yule, W. (1994). Reading And Other Learning Disabilities In: Edıtör M. Rutter, E. Taylor, L. Hersov. Child and Adolescent Psychiatry Modern Aprroaches, 647-665.

7. Sarıpınar, E.G. (2006).’Özgül öğrenme güçlüğü: Okuma Güçlügünde Akademik Beceri ve Duyusal-Motor İşlevleri Değerlendirme Testlerinin Kullanılabilirliği. Yüksek Lisans Tezi, Ankara Üniversitesi, Sosyal Bilimler Enstitüsü, Ankara.

8. Bonıfacc1, P, Montuschı, M, Lam1, L. and Snowling, M. J. (2014). "Parents of Children With Dyslexia: Cognitive, Emotional And Behavioural Profile”. Dyslexia, 20, 175-190

9. Acar, S. (2018). "Gelişimsel Disleksi ve Endofenotipik Yaklaşım: Nörogenetik, Nörobiyolojik ve Nörobilişsel Temeller”. Dil Konuşma ve Yutma Araştırmaları Dergisi, 1(2), 62-91.

10. Yangın, S, Yangın, N, Önder, V. ve Şavlığ, A. (2016). "Sınıf Öğretmeni Adaylarının ve Öğretim Elemanlarının Çeşitli Öğrenme Güçlüklerine Yönelik Farkındalıkları”. Education Sciences, 11(5), 243-266

11. “Okul Çağı Çocularının Kabusu: Dislkesi." (2021). Erişim adresi: https://www.sencard.com.tr/sen-programi/ailen/cocugu 
nuz-ve-siz/okul-cagi-cocuklarinin-kabusu-disleksi (Erișim Tarıhı:10.01.2021)

12. Balcı, E. (2019). "Disleksi Hakkında Öğretmen Görüşleri Ve Karşılaştıkları Sorunlar”. Ege Eğitim Dergisi, 20(1), 162-179.

13. Soriano-Ferrer, M, Echegaray-Bengoa, J.Y. and Joshi, R.M (2016). "Knowledge and Beliefs About Development Aldyslexia in Pre-Service and in-Service Spanish-Speaking Teachers"
Annals of Dyslexia, 66(1), 91-110. doi: 10.1007/s11881-0150111-1.

14. Uluçınar-Sağır, Ş. ve Bozgun, K. (2018). "Sınıf Öğretmenlerinin Öğrenme Güçlüğü Olan Öğrencilere Yönelik Yeterliliklerinin Farklı Değişkenler Açısından Değerlendirilmesi”. SETSCI Conference Indexing System, 3, 1116-1119. 